Warszawskie Studia Pastoralne UKSW

Rok X 2015 Nr 4 (29)

Jan Kazimierz PrzybyŁowski

\title{
PASTORAL CARE AS A HUMAN ACTIVITY
}

The pastoral care of the Church is of miraculous nature, therefore it is a domain of grace. The Holy - Ghost directs the pastoral activity - that is why it is of salutary nature. However those are the people who do the pastoral jobs. So it is the human's activity, as any other activity of a human as a person. A human being involves all himself into every activity. So the pastoral activity looks like - it has all the features of human's activity.

If so, it is an faulty (fallible) activity of human's side. ${ }^{1}$ Faultiness in this case would mean, first the imperfection in relation to the pattern of perfection. Also a mistake that may result from au proper activity is hidden in faultiness. Faulty activity is an activity without any pattern, perfection, and omitting objective rules. The human being acts in a faulty way if acts „on his own”. Finally faulty acting results from imperfection of the acting person. Faults are typical of subjective perception of human's activity, give him human, personal and individual character. Faulty activity therefore means activity of a human as an unique person, the one and the only one, but marked with the consequences of the original sin.

The faultiness of human's being activity differs him from the perfect activity of the God. If a human being was acting without any loads of weakness resulting from primary sin, his activity would be deprived of such uniqueness and exclusivity, also subjective perception, that make his activity faulty. Faultiness, describing human's nature of acting is however not a negative feature it only helps to describe it in a perspective of the primary sin's results. Faulty, that is human's

\footnotetext{
${ }^{1}$ Faultiness means mental deficiency, deformation and irregularity.
} 
acting in contrast of the God's acting is an individual, subjective and imperfect one and needs the relations to the ideal indicating certain values, norms and rules resulting from them, but on the other hand it needs its relation to the second person and community.

The faulty activity, not losing its human nature, through its relation to the Gospel that includes all its values obtains the objective attributes. However relation with God makes the faulty activity authenticated ${ }^{2}$. Finally through its relation with the community it becomes positively or negatively verified. Those positively verified get I.D. Of the Community while those negatively verified have to undergo a reparation process.

People differ not with the good thing, for it joins them as a fruit of God's gift. People differ by imperfection of human's nature, that was infected by a primary sin and undergoes its affects. Faultiness of human's activity means individualization on the one hand, but on the other one the subjective perception. The first means acting "on one's own", and the second means "acting according to own principles" the man estimates his and others actions. That is the way people's activities have to be confronted together to search for what joins them and eliminate what differs - it is done within the community. ${ }^{3}$

Faulty actions may bring negative effects due to insufficiency of single acting and subjective self-esteem of them and the others. This is why the community enables verification of the single acting. If the pastoral care is the human's activity - it is faulty. However the question arises: what should be done to acknowledge the faulty action of the priest for the salutary one?

2 „Christ, new Adam (...) reveals fully a human to the human himself and manifests his hightest vocation" - does it in "Father's and His love secret revelation” (KK 22). It means that human's revelation in his dignity maybe done only in relation to God - it doesn't mean only notional relation, but taking full reality of human's existance into consideration. John Paul II Encyclica Dives in misericordic, 1 (DiM).

${ }^{3}$ It should be distinguished in particular people acting what they do on their own behalf following christian's conscience from what they do with their priests on behalf of the church, that is a sight and a guarant of transcendental human's nature. 
Before replying the idea of redemption should be prevised - it can be done only in relation to Jesus Christ. Jesus had redeemed every man, the entire man, the entire mankind and whole world through his pain, agony and resurrection. ${ }^{4}$ The redemption is of universal nature. Next a real God's creative invention reveals in redemption. God's dimension of redemption doesn't realize in dispensation of justice itself but in restoration of love - the creative power of human, owing which he again an access to the plentitude of life and the holiness that comes from God. Redemption brings the plentitude of the mercy's revelation. ${ }^{5}$ The creation is however finished in redemption. Creation and redemption despite their turning pouts make an unit in eschatological view. One cannot exist alone (without the second one). Those two condition mutually stipulate and give meaning to their beings. Redemption is a next stage for creation in a process of maturing to eschatological plentitude. If one introduced the idea of evolution, the transformation from creation to eschatology would be done through redemption. Redemption maybe described as attaining such perfectionism of development in an earthly reality. What is therefore the creature's lasting from redemption up to eschatological fullness. It is the time of redemption. Christ's platform of Messiah's that is the platform of mercy is just a platform of its People, of the Church. A cross is always in the centre of this platform, because the revelation of mercy's love riches its zenith. ${ }^{6}$ Until the "first things" hadn't passed away, it is the cross that another Apocalypse's worlds could be quoted: „I am waiting at the door and knocking: if someone hears my voice and opens the door, I shall enter it and I shall have supper with him, and he shall have supper with me (Ap3, 20). ${ }^{7}$

${ }^{4}$ Redemption is a final revelationof God's, that is the fulfillness, justice and love due to justice is based in love (DiM 7).

5 DiM 7.

6 An impressive meeting of transcendent God's justice with Love performs in the secret of the cross. This meeting is a "kiss" that mercy granted to justice (compare PS 85 [84],11). DiM 9.

7 Jesus wans to visit in all his kind - heartedness, all who experience temptations and troubles, in order to protect them against downfall in case of difficulties. So 
Redemption is first the Christ's redemption presence. The presence is just the most right understanding for only Jesus had justified the Men, redeemed the entire creation and shall redeem. The redemption's presence means life's focusing and all church's activity on Christ. Due to the Church is both the Christ's Flesh and the Christ community this is why redemption is an activity of all the Church's members in harmony with Christ such activity is perfect, that is it fulfills basic needs, that Christ had left to the Church.

Salutary activity is directing people towards Christ. It is the next feature of redemption. Church that really works directs its members towards Christ. The entire community has to focus on Christ, but also life of every its member should concentrate on Christ. Redemption is meaningful only when Church's role is the realization of redemption and its presentation. It means that every member of the community has to start individual cooperation in this act. The member of Church is in constant contact with Christ, yet also stays open to all relations with other members of ecclesial community. The next dimension of redemption appears here: realization. Realization of redemption is possible only in close realizations of individual people with God and in personal relation between members of the Church community. Redemption is a common and commune acting.

After all those explanations we can undergo to a closer description of the "pastoral care" understanding. The first understanding is

when His Body suffers, His Head covers with dew-drops. Then we should be on alert, for have to leave unasked. When you are asleep, and your hearts are not on alert, he goes away without even knocking. However if your heart is awoken, then he knoks and asks to be let in. There are doors of your soul and gates - someone said about: „Gates raise your summits and step aside, and open the door wide so the King of Glory could come in", if you want to raise the gate of your faith, the king of Glory will visit you, trough His triumpf of Victory he had undergone during His agony. Also justice has its gates. We can read words, the Lord had said trough His Prophet. „Open the gates of justice for me”. So soul has its doors and also has its gate. Christ comes to it and knocks to the door. Open them: He wants to come in, he desires to find His bethrothed on alert". St. Ambroży bishop comments to the Psalm 18 ${ }^{\text {th }}$ ( no. 12.13-14), in: Liturgy of Hours, V. 3 p. 987-389. 
misleading. If we start with lexical understanding, the pastoral care means the subjective pastoral activity, of which people are the subject. The misleading is approach towards pastoral care as the priests' activities - the priest - subjects towards the souls - objects, of course the soul is only a try of the human's being description, that should admit the soul for his greatest value. ${ }^{8}$ In such understanding we find out that redemption concerns the soul only, not the body, whereas the whole man is redeemed, and the final meaning of redemption is in the Man's resurrection, who shall have body, not only spirit in eschatological plentitude of. The idea "pastoral care” despite being rooted in theological language and also used in regular one, doesn't reflect the sense of the Church's salutary activity. We should be more precised.

Parenthood may give us some point. The church runs salutary activity that gives birth to people towards eschatological plentitude. Giving birth is the parents' common activity, so it would mean the Christ and the Church common activity. Christ gives birth like a mother and the Church as father participates in it. It means that redeemed man has „two parents”, while Christ and Church have children, that is persons participating in redemption.

Giving birth is next „giving the progeny to the world” - it is a process. Salutary activity is just such a process, that is going the progeny to the world, but in eschatological meaning. Redemption doesn't end in an earthy world but in the eternal one. Finally giving birth is a fruit of love that joins parents. Christ loves his Church and Church is completely devoted to love to Christ. Every member of Church is a fruit of Christ's and Church's love. If church runs salutary activing, it means, that it expresses this way its love towards Christ, and Christ expresses his love towards Church.

Pastoral's activity however cannot be identified with giving birth. It is certainly the essence of salutary mission of Church according to principle: Church gives birth to Church. ${ }^{9}$ The salutary activity of

${ }^{8}$ But then if a Man gains the whole world, but his soul is hurt. (Mt 16, 26).

9 Nam et Eccelesia quotidie gignit Eccelesiam. St. Beda, Revered Explanatio Apocalipsis, lib. II, 12: PL 93, 166. 
Church is however closer to description "parenthood” - what means parents care. And it doesn't matter if it is newborn baby or not. You become parent during conception. The Church does parental functions. It is a function of a parent, that is and father and mother that also fulfill works belonging to a patron, teacher, tutor, advisor, master, authority. The priest should be prepared to parental acting, so he needs formation, that comes through mature reflexing, also practical use and includes kind of a spirit being its support, source of energy and impulse towards development ${ }^{10}$.

Describing "pastoral care" as "parenthood", is a need to precise miraculous and human's aspects of such activity. First parenthood is an activity according to objective principles resulting from faith in Jesus Christ. It is miraculous dimension of such activity. Due to parenthood is human's activity and is conditioned by its history ${ }^{11}$ this is why it gets human's unit's individual and subjective character. Objectification, realization and communization of this activity needs faith in Church, that is a "general sacrament of redemption"12. Participation in pastoral care Jesus 's love is the essence of parenthood that makes the principle and power of this salutary activity. ${ }^{13}$

Parenthood means both: the activity and the way of behaving of the Church's members together with feelings and way of behaving of Christ - the Good Priest. By using parenthood we mean priests parent's activities that owing to pouring out the Holy Ghost in the sacrament of consecration participate more in the pastoral love of Jesus. Secular worshippers participate in such pastoral love because of the Baptism. People are „called to a new life in which we don't lose anything but were deprived from the unfortunate state of primary sin, and all what is people's may create patterns of perfectionism and giving abundant and sacred fruit. So, the Christian's name and the Baptism should nicely move the conscience of every Christian

\footnotetext{
10 John Paul II, Apostols Adhoration Pastores dabo vobis, 57 (PDV).

11 We mean the real social - cultural and church's situation.

12 KK 48.

13 PDV 57.
} 
in a way, like during primary Church times, he had found it as an Enlightenment that brought the light of God. Truth to his soul, that would open the heaven, would light his present life and would add power towards watching God in His eternal happiness". ${ }^{14}$

Parenthood of secular worshippers has its origin in Baptism, owing which they make „ontological” community of pupils and Christ's believers. The secular worshippers become the members of the Church and their task is to be the more aware of community life and acting. Parenthood as a part Jesus's pastoral love should be based on honest awareness of vocation and responsibility for that special grace, the only one and unrepeated, owing which the Christian creates the Christ's Body in the Community of God's People. „This principle, that is a key rule of Christian's Apostol's and pastoral „praxis”, the practice of inner and social life - should be attributed to all and to everybody relatively in a right proportion. The pope has to use it to himself and every Bishop. Too all priests, monks and nuns should obey this principle. All couples and parents, men and women have to shape their lives. People of all professions from those on the top, to these who do the simplest jobs". ${ }^{15}$

If we want to use the idea: parenthood regarding salutary activities we have to resign from the idea: pastoral care. It is the try only to additional qualification and modernization of hitherto used ideas and theological and pastoral words adjusting to present theological lexical norms. It requires further researches and introduction of next ideas, that shall enable to describe contemporary Church its life and activity in a new way.

It seems that the dialogue with teenagers maybe a good checkup for pastoral theology. John Paul II emphasized by analyzing present problems of young people, that „they have stronger than adults tendencies to Christian's faith subjective perception and also to the partial and conditioned participation in the Church's life and mission and the sometime the youth's pastoral care that is brave and adjusted to our

14 Paul VI, Encyclica Ecclesiam suam, 39.

15 John Paul II, Encyclica Redemptor hominis, 21. 
times comes into being with difficulties in the Church's community. There is a risk that the youth all by themselves with their fragile mental resistance shall be frustrated and adults that do not experience the faith in a mature way, so they are not an credible patterns. It is obvious, that it is difficult in such situation to show the plentitude of Christian's life in the Church and behave them in it" ${ }^{\text {"16 }}$. It means that pastoral theology ought to be constantly confronted with the youth thinking, that may play the role of the „barometer” for checking usefulness of contemporary practical theology in Christians life. Those problems, however require further scientific reflection.

\section{Summary \\ Pastoral Care as a Human Activity}

The article presents the human aspects of the pastoral care of the Church. Man in every business engages the whole person. So it looks like the pastoral-it has all the characteristics of a human activity. If so, is this a faulty (fallible) human side. Impairment, specifying the nature of the human activity, it is therefore not a negative feature, and only serves as a descriptive name. Malfunction or human action, in contrast to the action of God, is a separate, individual, subjective, imperfect. This action therefore needs, on the one hand, to the ideal reference pointing to specific values, and the resulting standards and operating principles, and, on the other hand, I need a relationship to other individuals and to the community.

Jan Kazimierz Przybyłowski, the priest of Wloclawek Diocese, full professor, completed specialist studies on Faculty of Pastoral Theology in Catholic University of Lublin with doctors degree in 1993. He was qualified as assistant professor in UKSW Stefan Wyszynski's University in Warsaw in 2001. On $25^{\text {th }}$ of January he was honored with the title of theological sciences. Since $2002-$ he is the Pastoral Theology and Auxiliary Sciences Head of Department at the UKSW in Warsaw in 2001. 2008-2010 - pro Dean at Theological Faculty of UKSW, 2010-2012 - pro Rector for financial and science matters in UKSW. An author of several dozen science articles and several books, among others "Meaning of new evangelization in the youth's pastoral care. Pastoral study

16 PDV 8. 
(Lublin 2001); Behavior Function in ecclesial theory and practice. Theological - pastoral care study. (Warsaw 2010). „How do Polish youth pray? Social study, Warsaw 2013. „Role of new evangelization in Church and World. New dress without wholes and patches (ŁK 5, 36)" Warsaw 2014.

\section{Bibliografia}

M.R. Cohen, Reason and Nature, New York 1931;

A. Ballestrero, Vieni e seguimi, Casale Monferrato 1991;

H. Urs von Balthasar, Kim jest chrześcijanin?, Kraków 1999;

M. Dziewiecki, Wyznawać wiarę dzisiaj, Sandomierz 1999;

W. Gabara, Nauka o organizacji i zarzadzaniu. Kierunki i tendencje, Warszawa 1989;

W. Goddijn, Rola kapłana w Kościele i w społeczeństwie, w: Ludzie - wiara Kościót. Analizy socjologiczne, red. B. Cywiński, Warszawa 1966;

L. Hogben, Science for the Citizen, New York 1938;

J.G. Hutchinson, Management Strategy and Tactics, New York 1971;

W. Jacher, Człowiek i praca, alfabet wiedzy o pracy ludzkiej, Opole 1979;

P. Jaroszyński, Etyka - dramat życia moralnego, Warszawa 1993;

T. Kotarbiński, Traktat o dobrej robocie, Wrocław-Warszawa-Kraków-Gdańsk 1975;

M A. Krąpiec, Człowiek i prawo naturalne, Lublin 1975;

M. A. Krąpiec, Ja - człowiek. Zarys antropologii filozoficznej, Lublin 1974;

M. A. Krąpiec, U podstaw rozumienia kultury, Lublin 1991;

L. von Mises, Ludzkie działanie, Warszawa 2007;

S. Nowosad, Teologia moralna ogólna, Lublin 1994;

I. Mroczkowski, Osoba i cielesność. Moralne aspekty teologii ciała, Płock 1994;

H. Muszyński, Rozwój moralny, Warszawa1983;

M. Pokrywka, Osoba - uczestnictwo - wspólnota. Refleksje nad nauczaniem społecznym Jana Pawła II, Lublin 2000;

G. Reale, Podstawowe pojęcia „Osoby i czynu” [w:] Jan Paweł II. Fides et ratio. Tekst i komentarze, red. T. Styczeń, W. Chudy, Lublin 2003;

L. Rougier, Les Paralogismes du rationalisme, Paris 1920;

L.G. Tirala, Geist und Seele, München 1935;

Tomasz z Akwinu, Summa Theologiae, Roma 1984;

T. Tomaszewski, Z pogranicza psychologii i pedagogiki, Warszawa 1970;

K. Wojtyła, Osoba i czyn, Kraków 1969;

K. Wojtyła, Miłość i odpowiedzialność, Kraków 1962. 